\title{
TRADUÇÃO
}

\section{Sobre a teoria do Estado do socialismo e do bolchevismo ${ }^{1}$}

\author{
Otto Kirchheimer
}

Independentemente de o liberalismo ter querido se certificar de que os âmbitos culturais permanecessem fora do Estado, ele se satisfazia com o fato de, ao invés de aniquilar o Estado, conquistar, no Estado, uma posição de poder equivalente a sua posição econômica. Nessa luta, que sempre permaneceu repleta de respeito e de admiração secreta pelos poderes representantes desse Estado, a constituição [Konstitution] era sua arma. 0 fraco conteúdo político próprio do liberalismo fez com que ele sucumbisse duas vezes à vontade de poder de um Napoleão na França, enquanto que, na Alemanha da época de Bismarck e pré-Bismarck, ele renunciou repetidamente à sua independência perante o poder estatal. A constituição e a ideia de Estado de direito em geral - em cujo verdadeiro significado o liberalismo depositava excessiva confiança - deveriam ajudá-lo a fixar as camadas dominantes da nobreza em um âmbito de atividade precisamente regulado. Como, além disso, eles tinham apenas sua posição econômica como arma, esse processo foi razoavelmente longo. Esse atraso trouxe consigo o fato de que a última parte da luta foi conduzida já sob a irrupção da classe trabalhadora, que nesse meio tempo havia se tornado um fator político. ${ }^{2}$ Assim, a classe trabalhadora passou a ter uma relação mais estreita com o liberalismo por meio do posicionamento comum em um front contra o semiabsolutismo feudal. No abismo para o qual necessariamente eles precisariam trazer seus interesses econômicos opostos, a luta por liberdade política e de visão de mundo - à qual o liberalismo deu prosseguimento como uma herança tradicional tanto naqueles lugares onde ele havia praticamente abdicado de sua liberdade de ação política quanto na Alemanha - foi um aglutinador bem-vindo que continuou a fazer efeito até os dias de hoje na social-democracia da Europa ocidental. A luta por liberdade política, que os partidos estatais liberais conduziam para efetivar sua demanda por poder no âmbito político, era relativamente não perigosa na

1 Kirchheimer, O. Zur Staatslehre des Sozialismus und Bolschewismus. Zeitschrift für Politik, v.17, 1928, p.593-611, republicado na coletânea organizada por Wolfgang Luthardt: Kirchheimer, O. (1981). Von der Weimarer Republik zum Faschismus: Die Auflösung der demokratischen Rechtsordnung. Frankfurt: Suhrkamp, p.32-52. [Nota da tradutora (N. T.)]. Tradução de Bianca Tavolari.

2 A descrição mais concisa desse processo pode ser encontrada em Friedrich Engels, na Introdução a Karl Marx, Klassenkämpfe in Frankreich, p.5; mas o adversário também julga da mesma forma: Lorenz von Stein, Der Sozialismus und Kommunismus im heutigen Frankreich. 
medida em que a manutenção da unidade política do Estado garantia uma mesma base nacional comum. Mas essa base comum deixa de existir assim que a irrupção enérgica da classe trabalhadora, com a conquista da assim chamada democracia - ou seja, com o tratamento político igualitário e pleno, sem estar vinculado a qualquer qualificação que ensejasse censura -, deu um fim provisório a essa luta que ultrapassava os objetivos políticos do liberalismo. Ao mesmo tempo, com isso desaparecia o pressuposto valorativo que é ainda mais essencial para uma democracia - independentemente de que ela possa servir de forma para uma ideia deste tipo. ${ }^{3}$ Isso porque no momento em que uma grande parte do povo que não foi excluída do tratamento político igualitário deixa de reconhecer o valor comum como se fosse seu, no momento em que entra em colisão com ele, para o povo a democracia perde seu significado original, o significado da participação de cada indivíduo numa síntese existente de todos, em que há o reconhecimento de um valor comum.

Mas a história do século XIX - o palco da luta e da vitória final da democracia esqueceu, sob a impressão dessa luta feroz, de perguntar depois qual seria o conteúdo possível e sempre mutável do novo governo do povo; ${ }^{4}$ uma demora que parece suficientemente compreensível em razão da igualdade absoluta que se passou logo a pressupor entre povo e democracia, por um lado, e liberalismo e burguesia, do outro. Porque com isso a oposição foi transportada do puramente político para o social e, desde então, determinadas representações sociais de homogeneidade se escondem por detrás do termo "democracia”. Nesse sentido, a democracia também é reconhecida por autores socialistas; um reconhecimento que é certamente enfraquecido pela universalidade do valor em nome do qual o socialismo quer ser democrático; isso porque, por meio das demandas de igualdade social que o socialismo coloca para a democracia, essa já passa a ser entendida como uma passagem à condição de não-ser-mais-Estado, à condição de sociedade sem classes. No entanto, nenhuma unidade de valor determinada a priori faz parte das características constitutivas da democracia de valores [Wertdemokratie], mas unicamente uma unidade de valor que aponta para além do tratamento igualitário puramente político. Nesse sentido, a "democracia”, que foi conquistada na Alemanha depois do fim da guerra e, em outros países, em parte ainda mais cedo, adentra numa oposição aguda. ${ }^{5}$ Sem levar qualquer

\footnotetext{
3 Sobre as questões estruturais da democracia, cf. W. Becker em Schildgenossen, setembro de 1925. 4 Já Proudhon fazia uma reclamação altamente comovente sobre a mutabilidade das ideias dominantes no âmbito da democracia em: De la Justice dans la Révolution et dans l'Église, tomo 1, p.10.

5 Essa oposição entre, como vamos chamar aqui, a democracia formal e a democracia de valores também perpassa todo o livro de Max Adler, Politische oder soziale Demokratie; a caracterização de democracia política e social é um estreitamento da oposição entre democracia formal e democracia de valores, mas a expressão "democracia política" é infeliz, já que toda a democracia, forma fenomênica da vida estatal, é política. Aqui se mostra a necessária contradição da formação puramente socialista de conceitos: não se consegue prescindir das próprias categorias políticas mesmo quando se quer pensá-los em termos de categorias apolíticas.
} 
pressuposto valorativo em consideração, ela designa apenas um estado de tratamento político igualitário universal. 0 traço característico de uma democracia formal ${ }^{6}$ é não possuir valores que poderiam ser contrapostos a contra-valores determinados, a não ser que se entreveja, nessa liberdade em relação aos valores, um valor em si mesmo. ${ }^{7}$ Ela é a forma em que as classes e seus valores se cruzam e se encontram. Dito mais precisamente, ela é a forma em que, num determinado momento da luta de classes, as forças opostas se agrupam. A questão é a seguinte: como o governo é de todo possível sob essas circunstâncias e quem decide sobre quem deve tê-lo em suas mãos? Numa democracia qualificada por uma representação valorativa comum, a maioria de votos significa a decisão sobre o melhor modo de realização das representações valorativas comuns. ${ }^{8}$ Se não existe um valor comum, então não é completamente evidente por que a maioria deve decidir, já que essa decisão da maioria equivaleria à submissão sem luta da minoria ao adversário político. Isso pode ser melhor percebido a partir do fato de que este estado de longo prazo de uma submissão sem luta é designado por "ditadura” numa literatura socialista e, aqui, "ditadura” é pensada menos como um conceito caracterizador da exceção ${ }^{9}$ e mais como não-evidência de um tal ato de submissão. Os pressupostos para a existência da democracia formal são, portanto, os seguintes: um equilíbrio aproximado entre as classes que lutam entre si e o acordo tácito que daí resulta, enquanto essa situação de equilíbrio perdurar, para deixar decidir por meio do voto e seu eventual resultado de maioria sobre quem deve assumir o governo. ${ }^{10}$ Esse governo assim estabelecido não é livre em suas decisões, uma vez que aquele que eventualmente for vencido nesse procedimento de adição amplia o sistema de proteções constitucionais herdado do liberalismo em seus menores detalhes. Aqui, naturalmente, desempenha um certo papel a questão de qual classe ou qual grupo, com sua visão de mundo, conseguiu inscrever partes de seu programa

6 Karl Renner tem em vista apenas a democracia formal em suas considerações no caderno de dezembro de 1926 da Gesellschaft. [Como não há qualquer texto de Renner no caderno de dezembro de 1926 da revista Die Gesellschaft, Kirchheimer provavelmente se refere ao artigo Der Streit um die Demokratie, de Renner, publicado na mesma revista, no primeiro caderno de 1927. (N. T.)]

7 No mesmo sentido, Kelsen em Sozialismus und Staat.

8 Cf. a passagem clássica de Rousseau, Contrat social, livro IV, cap. 2, Des Suffrages. "Quand donc l'avis contraire au mien l'emporte, cela ne prouve autre chose, sinon que je m'étois trompé et que j'estimois être la volonté générale, ne l'étoit pas". Completamente conforme a esta ideia: Max Adler, Politische oder soziale Demokratie, p.85.

9 Sobre isso, Carl Schmitt, Die Diktatur e Politische Theologie.

100 problema do estado de equilíbrio apareceu como problema de contrabalanceamento na época da monarquia. É interessante a constatação de Aulard (Politische Geschichte der französischen Revolution, II, p.44) de que a burguesia almejava, por meio da pessoa do rei, um relativo contrabalanceamento entre povo e burguesia, sem com isso querer abdicar de seu poder de fato. Mas o povo não compreendeu sua posição favorável e ajudou a burguesia contra o rei (p.46). 0 liberal Rotteck compreendeu bem o principal significado desse processo como um ensaio para a história política do século seguinte, na medida em que ele faz a severa acusação de que a monarquia teria forçado a burguesia a, na Revolução Francesa, apelar ao povo (Geschichte vom Anfang der historischen Kenntnis bis auf unsere Zeit, vol. IX, p.83). 
na lei processual desse sistema constitucional de proteção - a constituição - e que, assim, consegue escapar das eventuais oscilações do estado de equilíbrio, por meio da exigência da maioria de dois terços, e de qualquer ataque pela duração de tempo do sistema. Uma observação da Constituição de Weimar a partir deste ponto de vista ofereceria exemplos instrutivos. Assim, a ideia de Estado de direito passou gradativamente por uma profunda troca de função [Funktionswechsel] ao sair do círculo de pensamento e das mãos dos partidos constitucionais em direção ao amplo plano de luta entre povo e classes proprietárias. Originariamente o tímido meio de luta das camadas de "posses e formação", para quem se tratava especialmente de consolidar a exclusividade de seu domínio financeiro ${ }^{11}$ e de não expor a segurança de suas ações privadas aos perigos de um sistema judicial incerto, a ideia de Estado de direito se tornou a linha divisória de dois grupos em luta, em que ambos estão muito distantes para perceber nela a lei definitiva da distribuição interna de poder. Esse acordo tácito, que é o fundamento da existência da democracia formal, só era suportável para os grupos em luta se os limites de poder do governo fossem demarcados o mais estreitamente possível, se lhe fosse concedido o mínimo possível de poder de decisão de fato, mas que, para isso, uma série de funções administrativas determinadas de maneira precisa pela lei lhe fosse transferida; funções administrativas que, em grande número, seriam inteiramente recriadas depois que a tentativa do liberalismo de retirar completamente a regulação das relações econômicas do Estado não se comprovou nem viável e nem tampouco desejável. ${ }^{12}$ Mas sobre cada função administrativa se elevam as instâncias que deveriam arrancar a decisão da atual distribuição das forças sociais para transportá-la para a esfera do direito. Caminhase para a juridificação [Verrechtlichung] em todos os âmbitos, procura-se desviar de toda decisão que seja de fato de poder, quer se trate do poder ditatorial do presidente do Reich ou da resolução de conflitos trabalhistas; tudo é neutralizado pelo fato de que é juridicamente formalizado. Apenas nesse momento começa a verdadeira época do Estado de direito. Isso porque esse Estado está embasado apenas em seu direito. Uma decisão tomada só se torna de todo tolerável se tiver um efeito o mais incolor e o menos autoritário possível, se por meio dela seja provocada a crença de que ela teria sido tomada por juízes independentes ${ }^{13}$ e segundo a livre convicção. 0 paradoxo se tornou fato; o valor da decisão está no fato de que ela é uma decisão jurídica, de que ela é proferida por uma instância reconhecida universalmente, mas

11 No Estado formal-democrático, o direito orçamentário perdeu completamente seu antigo significado, já que, com a possibilidade de troca de governos, o controle permanente exigiu um caráter altamente subsidiário.

12 A ideia do Estado-administração [Verwaltungsstaat] encontra sua representação mais pronunciada em Cunow, Marxsche Staats- und Gesellschaftstheorie, e também no livro de Renner sobre a guerra, Krieg, Marxismus und Internationale.

13 Ver, sobre isso, as observações de E. Rosenstock, Vom Industrierecht, p.167. 
que, mesmo assim, ela contém o mínimo possível de decisão de mérito. 0 Estado vive do direito, mas ele não é mais direito, é um mecanismo jurídico, e todo aquele que acredita tomar a condução dos assuntos do Estado recebe em suas mãos, ao invés disso, uma maquinaria jurídica que demanda dele tal como a um maquinista lhe demandam as seis alavancas que têm de ser por ele operadas. ${ }^{14} 0$ elemento do Estado de direito em sua forma agora visível depois da superação do liberalismo puro, a transposição específica das coisas do plano dos fatos para o jurídico-mecanicista, é a característica essencial do Estado na era do equilíbrio das forças de classe. Se retirarmos, com cuidado, as coisas que não suportam juridificação em razão de seu caráter incondicionado [Unbedingtheit] - tal como a religião e o serviço militar -, então o que sobra é um puro mecanismo jurídico.

A questão acerca da Revolução Russa, do Estado soviético, é a questão sobre se lá se tratou da destruição de uma maquinaria jurídica como essa, sobre se o Estado russo que foi exterminado também teria sido, da mesma maneira, uma forma de dirimir [Austragung] as oposições de classe. Isso deve ser completamente negado. O Estado oficial russo tinha uma ligação das mais estreitas com a lgreja ortodoxa russa; seu líder, o czar, era ao mesmo tempo o chefe da Igreja; uma razão a mais para os intelectuais orientados para o ocidente, a burguesia liberal, não terem conseguido ganhar influência; seu significado histórico - significado que as camadas correspondentes da Europa ocidental não perderam até hoje - é absorvido no movimento revolucionário geral e corresponde ao curto interlúdio entre o império czarista e a república de conselhos.

A formulação concisa daquilo que o Estado russo pré-revolucionário representava pode ser encontrada na obra Rússia e Europa, de 1867, de Danilewski - a bíblia do paneslavismo. Aqui, a missão político-cultural da Europa é contraposta à missão divina da Rússia e, como consequência, toda revolução é declarada incompatível com o caráter do povo russo. O Estado russo é um não-Estado, ele é só a forma terrena de expressão de uma missão desejada por Deus, um império repleto de valores, e, quanto mais perto chegamos da periferia do século XX, mais inconciliável se torna a oposição entre a verdadeira missão da Rússia e aqueles que a negam, até que ela se intensifica, no pensamento de Berdiaev (1927), um moderno pensador contrarrevolucionário russo, chegando à maravilhosa concepção de império de Deus como o verdadeiro e sagrado império russo e o império do anti-Deus como o demônio ateísta bolchevista. O que é particularmente interessante em Berdiaev não

14 O Estado-administração de Cunow e Renner reforça o conceito de "service" no pensamento francês e anglo-americano sobre o direito do Estado. Isso se mostra em Duguit (Traité de droit constitutionnel, vol. 2, p.52 e seguintes) pela inclinação de ver tudo que é direito público sob o ponto de vista de uma assistência para o processo social. O pensamento jurídico americano entende que é melhor abstrair de conceitos políticos de agrupamento, e aqui o conceito de "service" se torna um conceito de atribuição social de tipo completamente liberal - "serviço público para sua majestade, o cliente", como diz Hirsch (Amerikanisches Wirtschaftswunder, p.277). 
é apenas essa abertura de caminho para a oposição radical entre bem e mal, essa valoração completamente moral que ele concede a todos os processos estatais do império russo, mas muito mais a ascensão do conhecimento de que o bolchevismo rompeu completamente com qualquer meia medida e com qualquer neutralidade, que ele rompeu com o império do meio [Reich der Mitte], tanto que agora valeria tomar a última e verdadeira decisão. Assim, o característico do império russo era sua estrutura de oposição concisa combinada com seus conceitos morais-teológicos de bem e mal, que dominavam todo seu mundo de representações políticas. 0 problema de maior importância econômica era, como é sabido, a distribuição de terras.

Já Karl Marx havia sido levado a falar, em uma carta a Vera Zasulitch ${ }^{15}$, sobre essa estrutura completamente diferente das relações russas: de que a necessidade do processo de desenvolvimento capitalista se restringia à Europa e, na edição russa do Manifesto comunista, ele notou, no prefácio, que a derrota do absolutismo russo poderia ser o sinal de uma revolução de toda a Europa. Sob a liderança de Plekhanov, a social-democracia russa certamente caminhou como os partidos operários da Europa ocidental até a divisão ocorrida no ano de 1903, no Congresso de Londres. Ela também fez uma transição gradual, um desenvolvimento "orgânico" do absolutismo, passando pela democracia parlamentarista, até chegar ao ponto em que, pela primeira vez, o partido trabalhista teria a maioria parlamentar no Estado democrático. Esse comportamento levou, necessariamente, a ver um progresso constante no processo que foi do absolutismo até a democracia socialista completa e, especialmente, a ver o conjunto de acidentes [Akzidentalia] necessários em uma democracia formal com estrutura de equilíbrio (como as liberdades de imprensa, de reunião e instituições similares) como uma conquista duradoura, à qual havia sido atribuído um caráter de fetiche - para falar com Marx. Uma teoria do duplo progresso se formou entre os epígonos de Marx, que, depois dele, tiveram influência decisiva sobre a atitude dos partidos operários. ${ }^{16}$ Ao progresso do desenvolvimento da economia capitalista corresponde o progresso no desenvolvimento da humanidade, o progresso em sua educação para humanidade, que encontra expressão em seus respectivos métodos de luta. A paz pela qual morreu Jean Jaurès em 1914, comumente chamada de paz da Segunda Internacional, pertence a esta lista tanto quanto a crença numa maioria pacífica na democracia formal; essa democracia, que, segundo Kautsky, apresenta a luta das massas organizadas e esclarecidas como repleta de constância e prudência. Essa teoria do duplo progresso tem origem nos epígonos de Marx, não no próprio

15 Essa troca de cartas foi publicada pela primeira vez em 1924, pelo Instituto Marx-Engels de Moscou (volume I, $3^{\circ}$ tomo, p.263-286). Devo essa informação, bem como muitas outras, ao excelente escrito de Stählin (1926).

16 Schmitt observa a mesma relação quando fala da identidade imaginada entre ideias progressistasdemocráticas e a organização social-democrata. Die geistesgeschichtliche Lage des heutigen Parlamentarismus, 2. ed., p.32. Alguns exemplos, entre tantos outros: Renner, no ensaio já citado; Kautsky (1919); e altamente instrutivo: Kautsky (1921). 
Marx. Para o próprio Marx, o mundo político não era nada mais do que um reflexo do desenvolvimento econômico. Não é a maturidade do proletariado que leva ao dia da revolução social, mas é o processo de desenvolvimento do capitalismo o meio pelo qual o proletariado vai ser organizado e disciplinado. Segundo Georges Sorel (1921, p.199), a ideia de uma “continuité technologique" domina o pensamento de Marx.

Lênin, o reconhecido teórico do partido bolchevista, manteve-se afastado da teoria do duplo progresso por toda sua vida; mas a particularidade das relações russas o levou a rapidamente reconhecer que a dependência incondicional em relação à evolução econômica capitalista, à qual Marx vinculava o processo de maturação política do proletariado, não era de todo adequada para conduzir sua causa [Sache] à vitória. É certo que ele se prendeu à ideia da necessidade imutável do desenvolvimento econômico capitalista, bem como à ideia de que o progresso da humanidade se realizaria depois da vitória do socialismo; e, depois da conquista do poder, procurou efetivar esta última ideia num sentido completamente racionalista, materialista e orientado para o século XX; mas o conteúdo específico de sua ação e de sua teoria pertencem a uma outra área. Para efetivar o domínio do proletariado, Lênin substituiu a teoria do duplo progresso, a teoria da crescente humanização dos meios políticos de luta, por uma teoria da luta abrangente e sem reservas; no lugar do progresso que incluía a humanidade de todas as classes, ele incluiu a própria moral nessa luta, colocou-a a serviço de sua própria causa ao invés de ser seu servo. Para ele, essa luta é que cria o verdadeiro agrupamento [Gruppierung] da humanidade. "De acordo com nossa opinião", diz ele, "a eticidade é completamente subordinada à questão da luta de classes, ético é tudo que é vantajoso para o extermínio da antiga sociedade exploradora e para o ganho de poder do proletariado. Assim, nossa eticidade consiste apenas na disciplina fechada e na luta consciente contra a classe exploradora. Não acreditamos nas diretrizes eternas da moral e nós vamos desmascarar esta fraude; a moral comunista significa o mesmo que a luta pela consolidação da ditadura proletária”. No que diz respeito a sua intensificação, essas frases são a contraparte da tese de Berdiaev sobre Cristo e Anticristo, só que certamente toda representação religiosa foi adaptada ao âmbito político: no lugar do infiel, do Anticristo, entrou o inimigo político. De acordo com seu conteúdo, elas pertencem ao círculo de pensamento de Sorel, ${ }^{17} \mathrm{com}$ quem Lênin compartilha mais do que o ódio comum contra a superstição de progresso dos socialistas do parlamento. Eles têm em comum o fato de reconhecerem, na crença na conquista pacífica de uma maioria na democracia parlamentar, uma representação utópica. Mas utopias são projeções do pensamento humano; projeções racionais, não completamente imiscuídas na realidade, e que tendem para o futuro. Pareto já havia diferenciado entre utopias efetivas e inefetivas quando chamou o liberalismo de uma utopia

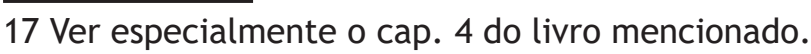


inefetiva e o socialismo, de efetiva (Pareto, 1902, p.65). Isso retrata as circunstâncias verdadeiras sob uma designação falsa. O liberalismo político e da economia política, a teoria da livre concorrência e os direitos humanos, o homo oeconomicus e o cidadão abstrato pertencem, na verdade, a uma mesma lista de representações utópicas. Isso porque eles são uma construção racional do pensamento que mistura o que é condicionado pelo tempo com o que é desejado, que projeta imagens de futuro; o que lhes falta é o efeito imediato no presente. Mas essa é a verdadeira linha divisória entre utopia e mito; enquanto a utopia que projeta o futuro distante permanece, em sua totalidade, impotente em relação ao presente, o mito tem efeito no presente e o forma automaticamente segundo sua imagem. ${ }^{18} 0$ mito vive no passado e no presente, o futuro só lhe é acessível na medida em que se corporifica, de acordo com a vivência, num pedaço de presente ou de passado.

Para Sorel, o mito do presente, o mito do proletariado, se corporifica na greve geral. Segundo a opinião de Sorel, Karl Marx se esqueceu da organização do proletariado em luta em favor da análise do desenvolvimento do capitalismo e, com isso, ficou num esquema racionalista que o levou para muito perto da utopia. Mas o sindicalismo precisaria tomar para si e realizar o que seria propriamente o conteúdo nuclear da teoria de Marx: a teoria da luta de classes. Com isso, é justamente o elemento marxista típico - a dependência funcional do movimento proletário do processo de desenvolvimento capitalista - que é colocado em questão, e, com isso, Sorel tornou a teoria da luta de classes independente, deu a ela um fundamento e um sentido próprios. Isso porque o que Sorel designa com "la force" serve, no fundo, exatamente ao que Marx entendia por processo de desenvolvimento capitalista: relações de força racionalmente calculáveis. Sorel contrapõe essas coisas racionais que pressupõem apenas paciência, compreensão e conhecimento, a um conceito político de agrupamento de tipo essencialmente distinto. "La violence", isso significa o ímpeto [Wucht] - para isso, Lênin usou o termo "élan russo" -, com o qual um grupo decidido se aproxima da sua vitória. É a última batalha, a "bataille napoléonienne", que, como conteúdo essencial do mito, reaparece também aqui. Mas com isso é a representação de uma luta por poder - uma representação na qual haviam se imposto a irrealidade de uma consciência e de uma luta de classes proveniente da necessidade de conhecimento, bem como seu necessário correlato de arrependimentos provenientes da ética individualista e da utopia - que é superada e substituída por uma ética de luta que encontra sua legitimação na grandeza e na capacidade de participação do próprio mito, mas que, assim, desloca a greve geral de sua esfera

18 A representação de um efeito imediato nas pessoas é típica do mito. Assim se lê em Sorel: "ll faut juger des mythes comme des moyens d'agir sur le présent" (p.180). Sem dúvida, a ideia de "agir sur le présent" só é encontrada, desenvolvida em sua pureza, entre os povos primitivos; ela corporifica uma atitude consciente da consciência pré-lógica. Ver Lévy-Bruhl, Mentalité primitive, em especial a p.94 sobre o caráter emocional do mundo primitivo de representações. 
econômica; não são mais trabalhadores assalariados que conduzem esta luta, mas os heróis de uma nova lenda que vão conduzir o início de uma nova época histórica. Os heróis do mito, os trabalhadores grevistas, são os puros, os melhores, os escolhidos para a última vitória e é por isso que é certa a vitória do proletariado agrupado em torno da bandeira da "violence", da violência [Gewalt] criadora, sobre "la force", a violência puramente técnica-econômica da burguesia; assim como a eterna vantagem de tudo que é irracional sobre o elemento racional, do mito sobre a utopia, é que um é devoto enquanto o outro calcula. 0 mito político tem a capacidade de evocar um agrupamento de valores políticos de tipo mais resoluto. Partindo da necessidade e da magnitude da luta definitiva, ele não tem nenhuma preocupação maior do que encontrar um inimigo, que na verdade não é mais inimigo; e ele espera conseguir que o desespero em encontrar uma saída impulsione a burguesia a se encorajar e a disputar a luta com a dignidade que dita seu significado. Seguindo assim uma antiga tradição, ele quer ver na imagem do burguês o inimigo por excelência. ${ }^{19} \mathrm{~A}$ teoria da "action directe" significa uma tentativa de restituir a política de sua imediatez, na medida em que ela, ao rejeitar toda instância intermediadora, ao rejeitar a esfera da humanidade neutra e do progresso, retira sua força e seus símbolos da esfera imediata da vida do presente. Para ela, a ligação estreita entre política e economia não é um perigo, já que o mito, como princípio da forma política, é suficientemente forte para superar todos os elementos de inércia. Para garantir a força da vontade de formação [Formungswillens] política, ele passa a defender a teoria das elites e reconhece, assim, um princípio de organização de cunhagem própria. Mas, com isso, a teoria de Sorel e a teoria do sindicalismo revolucionário entram em sintonia com a concepção oficial do leninismo, segundo a qual o partido comunista é o condutor do proletariado, sua única e verdadeira representação na grande luta contra o domínio mundial da burguesia, que, segundo a concepção de Lênin em Estado e revolução, representa o que há de falso, mau e imoral. ${ }^{20}$

É de importância fundamental determinar, para cada princípio político, como ele se posiciona em relação ao conceito de ditadura, em que medida ele leva o princípio da exceção em conta e the garante admissão. Se vejo corretamente, então três conceitos de ditadura se confrontam na literatura socialista. O conceito marxista de ditadura - formado numa época em que, pela primeira vez, questões de

19 Enquanto Eduard Bernstein, o representante típico da teoria do duplo progresso, já exaltava a integridade moral da burguesia nos anos noventa, Sorel e Pareto procuram, para além das tentativas de relativização do parlamentarismo e sem ilusões, apontar para o verdadeiro front de luta. Em fidelidade intelectual a Sorel, Johannet empreendeu a tentativa de contrapor a imagem do proletariado a uma imagem de valor da burguesia em seu Éloge du bourgeois français. Com isso, todos eles seguem a tradição de Bakunin: "L'honnêt homme, homme moral, c'est celui qui soit acquérir, conserver et augmenter la propriété", OEuvres complets, III, 127 e seguintes. 0 que há de mais recente sobre a imagem do burguês: Werfel (1926).

20 A concepção oficial da orientação partidária hoje dominante é de Stalin, Probleme des Leninismus. 
poder econômico afetavam, por si mesmas e de maneira inequívoca e desmascarada, representações políticas - conservou pouco conteúdo político próprio. Sem valoração política, ele caracteriza o momento em que o processo do desenvolvimento da economia capitalista chegou ao ponto em que a conquista do poder pelos trabalhadores tem finalidade e sentido. Seus sucessores, os representantes da teoria do duplo progresso, tentaram dissolver a representação de ditadura em duas linhas que correm em paralelo, uma do progresso técnico-econômico e outra do progresso político-humanitário: de modo a encontrar na democracia parlamentarista, abrangendo ambas as linhas, o princípio político formal definitivo da era capitalista. Então, para eles, a ditadura foi deslocada do mundo da realidade política para o da utopia, que, vinculado às "leis da economia" de Marx, continha a forma de uma “transição orgânica”. Essa mistura de desenvolvimento econômico e democracia, maioria e humanidade, fez com que ficasse fácil para os bolcheviques combater a crítica que foi levantada contra sua representação de ditadura, vinda das fileiras dos adeptos da teoria do duplo progresso. A partir de respostas como essas - "A revolução não discute com seus inimigos, ela os esmaga; a contrarrevolução faz o mesmo e ambos vão saber suportar a acusação de não terem observado o regimento do parlamento alemão"21 - percebe-se todo o absoluto desprezo dos bolcheviques por esses métodos liberais de luta de terceira categoria, percebe-se que o mito político da revolução mundial apresenta um meio de agrupamento político e um princípio formal [Formprinzip] mais eficaz do que a utopia de uma possível maioria na democracia parlamentarista. A ditadura bolchevista está em oposição aos outros dois conceitos socialistas de ditadura, dentre os quais um mal pertence ao âmbito da ditadura política e o outro designa, sob o conceito de ditadura, o progresso político no momento em que nenhum progresso é mais necessário - como uma utopia confortável. 0 conceito bolchevista de ditadura é mais genuíno porque ele serve para a caracterização de um estado de exceção. A ditadura bolchevista é uma ditadura soberana, o que se deve reter, mesmo que também tenha surgido o tipo de uma ditadura de comissários ${ }^{22}$, uma "ditadura de pessoas individuais para processos determinados de trabalho em funções puramente executivas", como expressou Lênin (1918, p.39). A ditadura bolchevista não significa qualquer transição orgânica, seu caráter de exceção consiste no fato de que ela quer primeiro criar as pré-condições para realizar o Estado socialista de igualdade social. Daqui deriva uma série de medidas políticas que ela tomou e é característica de toda ditadura tomar medidas para a realização de suas representações de valor, medidas que estão, elas mesmas, em contradição com os valores a serem realizados. Para isso ela se serve da assim

21 Radek no prefácio a Bukharin (1918, p.23).

22 Sobre a distinção fundamental entre ditadura de comissários e ditadura soberana, ver Carl Schmitt, Die Diktatur. 
chamada democracia de sovietes [Sowjetdemokratie], que embora não constitua a "forma mais desenvolvida" da democracia, significa a tentativa intencional de conseguir entrada, na consciência das massas da população rural, de um círculo de representações pressupostas como indiscutivelmente corretas. Essa participação nas coisas estatais deveria servir à substituição, fracassada em seu conjunto, "des gouvernement des hommes par l'administration des choses" e, sobretudo, servethe todo o sistema de conselhos que corporifica a práxis da "democracia soviética" e significa a transposição do novo princípio formal, que já aparece no sindicalismo, para a realidade. ${ }^{23}$

No que diz respeito à eleição, seu significado não está, de forma alguma, em seu resultado. Não the é inerente nem mesmo o significado fraco usual entre nós, de que, a depender do resultado, a tripulação da maquinaria do Estado é trocada. 0 fato de que um valor dos próprios portadores de valor seja colocado em discussão não significa, de maneira alguma, que se deva votar sobre se ele está correto, o que é pressuposto como indiscutível. 0 valor das eleições russas não está em seu resultado, mas no próprio processo de votação. 0 critério das eleições russas é que elas são públicas. Então se pode dizer "sim", não dizer absolutamente nada ou praticamente não dizer nada (= sem partido). Mas quem diz "sim" o diz diante de toda a esfera pública e claramente se sobressai em meio a todos que não dizem nada; isso porque aquele "sim" serve ao valor que rodeia o governo soviético: o valor da integração, a consciência de sentir-se-participante, de ter-vontade-de-estar-junto. ${ }^{24}$ Assim, as eleições russas, mesmo sem possuírem um valor substantivo de decisão, criaram para si um valor político específico na medida em que se tornaram um fator de integração estatal.

No que diz respeito ao direito soviético, seu significado para a vida estatal não pertence apenas à mesma linha que a eleição. Abstraindo-se da medida própria

230 sistema de conselhos aparece aqui em nova forma. Originariamente a forma em que os grupos revolucionários atuavam, autônoma e politicamente, diretamente sobre a base da organização de classe e, ao mesmo tempo, sobre a base da organização profissional, ela ajudou a fundar o domínio dos bolcheviques (sobre a história de seu desenvolvimento intelectual: Über die Rolle des Agitators in Cromwells Heer; Bernstein, Sozialismus und Demokratie in der englischen Revolution; sobre o papel dos conselhos operários da primeira Revolução Russa: Trotski, 1907, p.76). Num desenvolvimento consciente do curso das ideias sindicalistas, os conselhos que derivam diretamente das empresas na Rússia são avaliados como portadores de funções políticas (administração, eleição).

24 A questão do caráter público [Öffentlichkeit] das eleições não é decidida na própria constituição, mas foram as comissões de governo, a quem cabe essa decisão, que decidiram, sem exceção, em favor do caráter público. Sobre o procedimento de votação que prossegue na assembleia eleitoral oficial, ver mais em Timachev, p.83 (contra os soviéticos). R. Maltzew em Komm. Internationale 1927, caderno 19, é interessante do ponto de vista da praxis da última eleição. A diferença entre voto secreto e voto público significa, na verdade, o rompimento mais agudo e imaginável com as representações e tradições parlamentaristas-individualistas-liberais. Ele extermina qualquer ideia de que, na eleição, o destino do grupo governante poderia ser decidido de alguma maneira. A eleição pública significa confirmação, aprovação, mas, de maneira alguma, decisão. 
de tecnicidade de todo direito da modernidade, inclusive o soviético, encontramos, para além de tudo isso, o caráter específico de nosso direito na relação inversa entre a falta de um poder substantivo de decisão e o aumento quantitativo desse poder, no desaparecimento das atribuições de valor por parte do Estado, numa formalidade e numa precisão mais técnico-jurídicas, em suma, no desaparecimento característico do Estado por trás de seu próprio mecanismo jurídico. A representação que Lênin (1918, p.30) fazia sobre a tarefa do direito é a seguinte: "Nota-se que a representação, herdada e influenciada pela burguesia, de que a justiça seria algo oficial e hostil ainda não foi definitivamente rompida. 0 fato de que precisamente a justiça é o órgão de ligação da população mais pobre com a administração do Estado não chegou suficientemente à consciência. Isso porque a justiça é o órgão de poder dos trabalhadores e dos pequenos agricultores, ela é um instrumento de educação e disciplinamento”. Rompe-se aqui com a concepção da justiça como aquela que se eleva acima dos litigantes, como terceiro independente, com aquela concepção do liberalismo que fez, nessa representação, sua necessidade se tornar virtude. Para tanto é restaurada a representação do caráter integral do direito que, desde o tempo do liberalismo, desaparece na Europa cada vez mais e que se extinguiu completamente no mecanismo jurídico da democracia formal. Onde houver Estado, seja ele democrático em seu conteúdo, seja em forma ditatorial, o direito é dito em nome de determinadas representações de valor. Por isso é inteiramente lógico que as garantias do judiciário russo não estejam em sua independência e inamovibilidade, mas em seu período limitado de eleição e no teste de sua confiança no serviço ao partido, feito anteriormente à eleição; que não estejam no seu vínculo à lei, mas que se baseiem em seu senso revolucionário de justiça. Aquele juiz de Moscou que recusou uma demanda - apesar da existência de todas as razões para aceitá-la porque feriria os interesses de um trabalhador caracteriza, em pequena escala, o que o governo soviético quer alcançar quando autoriza, segundo sua constituição, que uma apelação contra decisões das instâncias superiores seja feita ao Comitê Executivo Principal, uma corporação política. ${ }^{25}$ Aquela função integral do direito, que, dos pontos de vista do Estado de direito, foi caracterizada de maneira um tanto depreciativa como "valeur instrumentale" (Guetzevitch, 1925, p.314), condiciona simultaneamente que seu caráter é tão dependente dos objetivos colocados pelo Estado, que se chegou até mesmo a cogitar deixar o novo Código Civil russo valer por apenas dois anos. Assim se expressa o fato de que o direito russo não é um direito eterno, mas um direito temporal na mais aguda extensão. ${ }^{26} 0$ direito russo não precisa de uma “clausula rebus sic stantibus" especial porque ele é, ele próprio,

25 Cf. a Carta Constitucional russa de 6 de julho de 1923, Parte II, $7^{\circ}$ capítulo.

26 Sobre isso ver também o comentário de Rosenstock (1926, p.122). 
o direito da "clausula rebus sic stantibus". ${ }^{27}$ Essa ideia domina completamente a concepção russa de direito internacional; a irreconciliabilidade das oposições de classe deu vida ao Estado soviético, ela the serve e, por meio dela, os bolcheviques esperam dominar toda a Terra. É por isso que, para o Estado soviético, o direito internacional, no sentido tradicional da palavra, é a mais questionável entre todas as construções jurídicas. Como a Rússia soviética não reconhece uma comunidade de interesses de diferentes Estados que não seja mais do que de caráter técnico, ela não possui qualquer evidência para todo esforço de configurar a comunidade de direito internacional de maneira mais estreita e de apoiar a propaganda de paz. Para ela, o direito internacional não é um direito de paz, mas um direito de armistício. Como então a Rússia não vê qualquer possibilidade de entrar no conjunto das relações de direito internacional - cuja essência ela entrevê na estabilização de costumes e proposições jurídicas de um tempo que está morrendo -, ela precisa se servir, nesse período de transição (époque transitoire), de acordos especiais precisados com exatidão com as potências individuais. Como falta a mais silenciosa e mais fraca homogeneidade de interesses e pontos de vista que poderia formar a condição para a decisão em sentido jurídico, a Rússia precisa recusar não só o princípio da maioria nas relações de direito internacional, mas também toda a instância que reivindicar para si autoridade para decidir. ${ }^{28}$ Desta maneira, a Rússia soviética precisaria se tornar necessariamente o inimigo por princípio - e não, como a Alemanha, o inimigo ocasional - da Liga das Nações de Genebra. ${ }^{29}$ Como também o preâmbulo previsto para o primeiro projeto de Wilson, segundo o qual a finalidade da Liga das Nações deveria ser um governo ordenado dos Estados, ficou de fora, então a Liga das Nações, como protetora e defensora dos princípios formal-democráticos de legitimidade, permaneceu desde o primeiro discurso de Viviani até os dias de hoje numa oposição igualmente aguda à Rússia soviética. Pode-se perceber claramente a avaliação que se faz na Rússia sobre a Liga das Nações a partir de um discurso de Rykov (1925, p.2446): “A Liga das Nações é um vendedor que lida com povos e os vende, na forma de mandatos, aos assim chamados Estados civilizados”. Esse princípio formal-democrático de legitimidade serviu às potências como pretexto para finalidades imperialistas de intervenção na Rússia. O recurso da Inglaterra ao art. II da Convenção da Liga das Nações para sua intervenção na guerra entre a Rússia e a Polônia passou, no entanto, do ponto de vista do governo soviético mantido até hoje, por uma forte recusa expressa, mediante uma

27 Ver, sobre isso, os ensaios interessantes de Korovine e M. Guetzevitch na revista mencionada acima. 28 Sobre isso, Schmitt (1926a).

29 A partir disso se explica a constatação muito enganosa de Kunz em Z. f. Völkerrecht XIII, 4, p.584, de que o direito internacional russo seria caracterizado "por uma grave tendência reacionária". A palavra "reacionário" pertence a outros círculos de representação e pressupõe uma unidade política dada. Ela não diz nada para a luta dos Estados e das classes e precisa ser substituída por conceitos políticos de agrupamento de tipo mais abrangente. 
nota diplomática extremamente interessante de Chicherin, de maio de 1921. Fala-se aqui de uma "assim chamada Liga das Nações, de cuja existência se soube por meio de notícias de jornal" e enfatiza-se veementemente a incompatibilidade do art. II da Convenção da Liga das Nações com a soberania do povo russo trabalhador (Chicherin, 1921, p.559). O recurso parece peculiar no que diz respeito à soberania. Numa época em que o desmonte das representações de soberania ${ }^{30}$ era levado adiante prática e teoricamente na Europa, o bolchevismo se encontra na estranha situação de, na práxis, proporcionar ao conceito de soberania uma nova marcha triunfal - conceito a que ele havia negado o reconhecimento no plano teórico. 0 argumento de um escritor russo ${ }^{31}$ de que a república soviética chegou ao uso do conceito de soberania menos pela beleza de uma tese jurídica do que pelos "intérêts réels" da república socialista pode ser altamente interessante para a avaliação das teses jurídicas na Rússia soviética, sem todavia penetrar no problema propriamente dito.

$\mathrm{Na}$ Europa, o desvanecimento das representações do Estado nacional não aparece com mais clareza em nenhum outro lugar do que no fato de que as anexações coloniais e de outros tipos feitas depois da Paz de Versalhes não encontraram, como tradicionalmente, seu apoio moral na unidade nacional do povo; pelo contrário, foi preciso se valer da construção da Liga das Nações como depositário fiel para dar fundamento ao resultado desejado. Do mesmo modo como a fraqueza prática do conceito de soberania do Estado nacional se aclara com a necessidade de construções auxiliares ao Tratado de Versalhes, a dificuldade teórica fica nítida na impossibilidade de, na era das estruturas formais-democráticas de equilíbrio, encontrar uma resposta satisfatória para a questão de quem detém a soberania, questão que significa a decisão substantiva no caso de conflito. A Rússia soviética designou um portador da soberania determinado e conhecido, de maneira praticamente inconcebível diante das tendências de encobrimento de nossos tempos. Apenas por isso, já lhe teria que ser concedido ao menos o reconhecimento de, na história da teoria do Estado, ter empreendido uma tentativa de restauração em grande estilo; mas a novidade por princípio do conceito bolchevista de soberania está em ter separado, conscientemente e pela primeira vez, Estado e soberania. O bolchevismo ajuda

30 De maneira mais concisa em Laski (1919) e também Kurt Wolzendorff (1920). A questão da soberania está intimamente relacionada com a questão da força do princípio da forma política. Lá onde falta um princípio forte da forma, em que o Estado, como mecanismo jurídico, consiste apenas na forma das classes que se alternam no governo, sempre haverá pensadores que vão procurar tirar a última consequência por meio da eliminação do conceito de soberania. Então podemos, como Wolzendorff e Laski, proclamar, também juridicamente, a completa autonomia da economia, com a ajuda de um curso cooperativo de pensamentos. E, sem seguida, tal como aconteceu com Wolzendorff, falar apropriadamente em um "Estado puro", que, na verdade, nada mais é do que uma construção jurídica liberal limitada à polícia e à função de defesa. Ou falar como Laski de uma "cooperative sovereignty", cuja expressão última significa, no entanto, apenas um encobrimento. Em uma outra passagem, ele diz com mais clareza: "The real rulers of a society are undiscoverable, but with the real rulers must go sovereignty".

$31 \mathrm{E}$. Korovine no artigo já citado da Revue..., p.299. 
a dissolver a ligação - herdada historicamente e que se tornou insustentável da soberania ao Estado na medida em que, proclama, encaixando na lacuna que surgiu, a soberania da classe no lugar da soberania estatal. Essa soberania não está vinculada a qualquer limite estatal, ela é, segundo sua tendência, universal. Com isso, a questão da intervenção também ganhou um outro aspecto. A intervenção dos Estados nacionais imperialistas encontrava seus limites no grau de saturação de suas economias. A política de intervenção da república soviética não conhece qualquer limite, ela é insaciável por princípio; isso porque o domínio da classe se estende potencialmente a cada integrante da população trabalhadora e cada membro da classe lhe dá ocasião para intervenções, seja porque ela se coloca numa posição de proteção diante dele, seja porque ela procura influenciar os destinos de outros países por meio dele. Mas com isso levanta-se a questão de se a Rússia soviética ainda é um Estado. A quem reivindica ou exerce um direito ilimitado de intervenção falta o que é específico do Estado: restringir a si mesmo em algum ponto qualquer do mundo. Mas com isso não se diz que a Rússia soviética apresenta algo menos do que um Estado; pelo contrário, ela recuperou o caráter integral do direito e das eleições, mas para colocá-los a serviço de agrupamentos mais abrangentes do que antes. Com sua ajuda e com a ajuda do mito político da revolução mundial, a Rússia alinhou as forças políticas de maneira nova, rasgou as lacunas no lugar das quais o Estado permaneceu por bastante tempo ao longo do século XIX. A forma do Estado ainda existe; mas do próprio Estado há algo a menos, ele se tornou um mecanismo jurídico em torno do qual o entusiasmo foi ainda suficientemente grande para uma teoria do duplo progresso. Esse Estado, que não é mais Estado, tampouco pode ter inimigos, já que ele não possui mais qualquer forma de expressão política. A hostilidade dos portadores do mito político da revolução mundial, que vê na Rússia apenas seu ponto de partida, orienta-se contra as potências que estão por trás dele. São os grupos de potências capitalistas com suas políticas imperialistas, de um lado, e os portadores da teoria do duplo progresso, os mantenedores do mecanismo jurídico, a socialdemocracia e a pequena burguesia, do outro lado, para quem a hostilidade absoluta e inconciliável do bolchevismo se dirige.

\section{Referências}

Adler, M. (1926). Politische oder soziale Demokratie: ein Beitrag zur sozialistischen Erziehung. E. Laub.

Aulard, A. (1924). Politische Geschichte der französischen Revolution, II. Duncker \& Humblot.

Bakunin, M. OEuvres complets, III. Edição e data não citadas.

Becker, W. (1925). Demokratie und Massenstaat. Die Schildgenossen, n.5, p.459-478. 
Berdiaev, N. (1927). Das neue Mittelalter, Betrachtungen über das Schicksal Rußlands und Europas. Darmstadt: Otto Reichl Verlag.

Berstein, E. Sozialismus und Demokratie in der englischen Revolution. Edição e data não citadas.

Bukharin, N. (1918). Das Programm der Kommunisten (Bolschewiki). Union Verlag.

Chicherin, G. (1921). Russische Korrespondenz, ano I, volume 2. 0 título do artigo não é informado.

Cunow, H. Marxsche Staats- und Gesellschaftstheorie. Edição e data não citadas.

Duguit, L. Traité de droit constitutionnel, volume 2. Edição e data não citadas.

Guetzevitch, M. (1925). Revue nouv. de droit intern. publique, tomo 7. 0 título do artigo não é informado.

Hirsch, J. v. (1926). Das Amerikanisches Wirtschaftswunder. Bln., S. Fischer.

Johannet, R. (1924). Éloge du bourgeois français. Paris: Les cahiers verts, Librarie Grasset.

Kautsky, K. (1919). Terrorismus und Kommunismus. Ein Beitrag zur Naturgeschichte der Revolution. Berlim.

. (1921). Georgien, eine sozialdemokratische Räterepublik. Eindrücke und Beobachtungen. Viena.

Kelsen, H. Sozialismus und Staat. Edição e data não citadas.

Korovine, E. Revue nouv. de droit intern. publique. O título do artigo e a data não são informados.

Kunz. Z. f. Völkerrecht, XIII. O título do artigo e a data não são informados.

Laski, H. (1919). The problem of sovereignty. Authority in modern state. Yale University Press.

Lenin, V. (1918). Die nächsten Aufgabe der Sowjetmacht. Promachos Verlag.

Lévy-Bruhl, L. (1922). La mentalité primitive. Paris: Les Presses universitaires de France.

Maltzew, R. (1927). Komm. Internationale, caderno 19. O título do artigo não é informado.

Marx, K. Die Klassenkämpfe in Frankreich. Edição e data não citadas.

Pareto, W. (1902). Les systèmes socialistes. Paris: V. Giard \& E. Brière.

Proudhon, P-J. De la Justice dans la Révolution et dans l'Église, tomo 1. Edição e data não citadas.

Renner, K. (1917). Krieg, Marxismus und Internationale. Stuttgart.

(1927). Der Streit um die Demokratie. Die Gesellschaft, caderno 1.

Rosenstock, E. (1926). Vom Industrierecht. Berlim.

Rotteck, K. v. Allgemeine Geschichte vom Anfang der historischen Kenntnis bis auf unsere Zeit. Edição e data não citadas. 
Rousseau, J-J. Contrat social, livro IV. Edição e data não citadas.

Rykov, A. (1925). Internationale Pressekorrespondenz. O título do artigo não é informado.

Schmitt, C. (1926). Die geistesgeschichtliche Lage des heutigen Parlamentarismus. - (1926a). Kernfragen des Völkerbundes. Berlim. - Die Diktatur. Edição e data não citadas. . Politische Theologie. Edição e data não citadas.

Sorel, G. (1921). Réflexions sur la violence. $6^{\text {a }}$ ed. Paris.

Stalin, J. Probleme des Leninismus. Edição e data não citadas.

Stählin, K. (1926). Rußland und Europa. Berlim.

Stein, L. v. Der Sozialismus und Kommunismus im heutigen Frankreich. Edição e data não citadas.

Trotski, L. (1927). N. Z. O título não é informado.

Werfel, F. (1926). Der Tod des Kleinbürgers. S. Fischer Verlag.

Wolzendorff, K. (1920). Der reine Staat. Tübingen: Laupp.

Recebido em: 17.01.2018

Aceito em: 18.04.2018 